\title{
Mark von Hagen (21 July 1954-14 September 2019)
}

\section{Frank Sysyn}

Canadian Institute of Ukrainian Studies, Toronto Office, University of Alberta

$\mathrm{T}$

he outpouring of tributes and grief on social media as news of Mark von Hagen's passing spread testified that he was not only an eminent academic and a scholar who had given unstintingly of himself to the profession. It showed above all how he had personally touched the lives of so many colleagues through his genuine interest in the research of others and his suffusive kindness and caring for all he worked with or encountered. These were qualities that made him open to new fields and to sharing the knowledge he had acquired. This made him an excellent teacher.

Here I write about my dear friend for the Ukrainian studies community, so I will not list in detail Mark's many accomplishments that will be discussed in many of the tributes being written for other audiences. Suffice it to say that he graduated from Georgetown University's School of Foreign Service (1976) and received an MA in Slavic Languages and Literatures from the University of Indiana (1978) and a PhD in History and Humanities from Stanford University (1985). He was an assistant professor (1985-89) and professor (1989-2007) in the Department of History at Columbia University, and also served there as associate director (1989-92) and director (19952001) of the Harriman Institute. From 2007 to 2011 Mark was chair of the Department of History at Arizona State University and then of that university's School of Historical, Philosophical, and Religious Studies and later a professor in the latter. His early scholarly work was on the military, social, and political history of the Soviet Union, culminating in his groundbreaking monograph Soldiers in the Proletarian Dictatorship: The Red Army and the Soviet Socialist State. Much of his later work dealt with Ukraine, albeit often through examinations of empires and nations, the history of war, and military history. But before dealing with these interests, I think it worthwhile to recall how Mark became a historian of Ukraine and an organizer of Ukrainian studies.

When Mark served as associate director of the Harriman Institute, during the years 1988-92 its Nationality and Siberian Studies Program was run by Professor Alexander Motyl, a specialist in Ukrainian politics. Alex remembers asking Mark to give a talk on Ukraine, to which Mark responded that he knew next to nothing about its history. But he took up the challenge, 
and that is how a seminal article by Mark germinated, subsequently stimulating the notable discussion on "Does Ukraine Have a History?" in the Slavic Review. In the interim were a whole series of interconnected events that would lead him to become involved with the newly forming Ukrainian Studies Program at Columbia and ultimately head the International Association of Ukrainian Studies (2002-05). Crucial, of course, were the break-up of the Soviet Union and the rise of an independent Ukraine, both of which took the entire historical profession unawares.

This was also the time that I entered the story peripherally. While I was moving to the Canadian Institute of Ukrainian Studies (CIUS) from Harvard after a year spent in Germany on a Humboldt grant, Paul Hollingsworth, a specialist in Kyivan Rus' who had been a researcher at the Harvard Ukrainian Research Institute, suggested that I get in touch with his Georgetown classmate Mark von Hagen, who somewhat later went on a Humboldt grant to Berlin. I looked him up in Berlin, and soon after I cajoled him to come to a conference on Polish-Ukrainian relations in KamianetsPodilskyi. I can still remember our endless ride from Kyiv to Kamianets in a train compartment whose doors kept swinging open and shut. I would like to think that that conference and our discussions on what the role of Ukrainian studies would be now that Ukraine was independent nudged Mark to take up the study of Ukraine.

Most important was that Petro Jacyk, the philanthropist who had endowed the Centre for Ukrainian Historical Research at the CIUS that I had moved to Edmonton to head, had also decided to fund the Ukrainian Studies Program at Columbia. Initially Mr. Jacyk had been approached by Richard Erickson, the director of the Harriman Institute, and Alex Motyl in the early 1990s, and in 1993 the Petro Jacyk Education Foundation endowed the Ukrainian program at Columbia. Mr. Jacyk was especially impressed that Mark, a non-Ukrainian, was treating Ukrainian studies so seriously. Unlike many scholars who were discovering Ukraine upon the break-up of the Soviet Union but investing little organized work to prepare for examining their new topic, Mark was willing to devote effort in learning the language and even speaking it. This talent became especially important after he became director of the Harriman Institute in 1995.

Mark's interest in Ukraine proved crucial for one of the largest international projects that the CIUS was involved in in the early 1990s. Zenon Kohut had taken up a position at the CIUS in the early 1990s, and he and I were interested in whether the new situation could spark a rethinking of Ukrainian-Russian relations. The Humboldt Foundation was offering grants for collaborative projects with North American academics, and Andreas Kappeler, our colleague at the University of Cologne, who agreed that Ukraine and Ukrainian-Russian relations should be a focal point of scholarly discussions, took up the idea of putting in an application. Mark 
heartily agreed with the need for such discussions and undertook a grant proposal from Columbia to the National Endowment for the Humanities, which, together with the Chopivsky Family Foundation, underwrote the early attempt to start discussions between Russian and Ukrainian specialists. The resulting "Ukrainian-Russian Encounter" project brought together scores of scholars in Russian and Ukrainian studies at four conferences in Cologne and New York in 1994 and 1995. Anyone who wishes to understand Mark's goals in this endeavour should read the introduction to the papers of the fourth workshop, published in a special issue of the Harriman Review (vol. 9, nos. 1-2, spring 1996) (Peoples, Nations, Identities). A selection of the other papers was published by the CIUS Press in 2003 as Culture, Nation, and Identity: The Ukrainian-Russian Encounter (1600-1945), with Mark as a co-editor.

Mark's dedication and enthusiasm made Columbia a vibrant centre of Ukrainian studies in the 1990s. His horizons went far beyond the gates of the campus as he drew various Ukrainian institutions in New York, such as the Shevchenko Scientific Society, the Ukrainian Academy of Arts and Sciences, and the Ukrainian Museum, into co-operative projects. The Shevchenko Scientific Society reciprocated by assisting in funding Columbia projects. Columbia's Ukrainian program found more constant support when the Ukrainian Studies Fund in the U.S. founded the Ukrainian Instruction Fund at the Harriman Institute in 2002. Mark's dedication to Ukrainian studies did not flag. He agreed to take over the presidency of the International Association of Ukrainian Studies in 2002 and organized the association's memorable conference in Donetsk in 2005. He became especially wellknown in the broader Ukrainian community when he was asked by the New York Times to study the role of Walter Duranty in covering up the Holodomor in the 1930s. Regrettably, his conclusion that the newspaper should advocate for revoking its reporter's Pulitzer Prize was not accepted by the Times. In 2007 Mark decided to take up a departmental chair position at Arizona State University (ASU). There he continued his dynamic activity in the profession and in Ukrainian studies. In 2008 he was elected president of the American Association for the Advancement of Slavic Studies. He advocated for the teaching of Ukrainian in ASU's language school. He also took up responsibilities as a professor at the Ukrainian Free University in Munich, where he lectured in Ukrainian and later served as dean of the Philosophical Faculty. He was active in establishing the Ukrainian-German Historical Commission and served on its advisory board. He also served on the Advisory Council of the CIUS and took part in CIUS conferences.

As Mark became more focused on the organizational side of Ukrainian studies, he devoted more of his scholarly work to Ukrainian topics. His War in a European Borderland: Occupations and Occupation Plans in Galicia and Ukraine, 1914-1918 illustrated how he combined his interests in military 
history, empires, and Ukraine. His numerous articles on these topics also dealt with the revolutionary years of 1917-20 (or, from another, Ukrainian, perspective, the liberation struggles). He was particularly enthused in taking over the editing of Pavlo Khrystiuk's Chronicle of the Ukrainian Revolution, a translation done many years ago at the CIUS but never published. Mark noted how unknown the Ukrainian events are even today by specialists in the Russian Revolution (1917) and the Russian Civil War (1918-21). Indeed, he advocated that we should republish John Reshetar's Ukrainian Revolution, 1917-1920: A Study in Nationalism, arguing that many of his colleagues had never read it. Mark's enthusiasm for the work of Khrystiuk, a man of the Left, was so convincing that it stimulated many scholars of the Ukrainian diaspora and of Ukraine who had adhered to more conservative visions of the period by participants and memoirists, such as Dmytro Doroshenko, Ievhen Chykalenko, Pavlo Skoropads'kyi, and Oleksander Lototsky, to reconsider Khrystiuk's role and his writing. Indeed, the W. K. Lypynsky East European Research Institute supported the project, in part because its board so respected Mark. Mark's goal was to introduce a Ukrainian perspective to those who had viewed the period only from Moscow's point of view and to stimulate Ukrainian specialists to reconsider their paradigms. He finished the draft of his introduction to Khrystiuk's work. The CIUS will have the honour of seeing that Mark von Hagen's vision comes out in print.

Works Cited

Kappeler, Andreas, et al., editors. Culture, Nation, and Identity: The Ukrainian-Russian Encounter (1600-1945). CIUS P, 2003.

Peoples, Nations, Identities: The Russian-Ukrainian Encounter. Special issue of The Harriman Review, vol. 9, nos. 1-2, spring 1996.

Reshetar, John S. Ukrainian Revolution, 1917-1920: A Study in Nationalism. Princeton UP, 1952.

Von Hagen, Mark. "Does Ukraine Have a History?" Slavic Review, vol. 54, no. 3, 1995, pp. 658-73.

---. Soldiers in the Proletarian Dictatorship: The Red Army and the Soviet Socialist State. Cornell UP, 1990.

---. War in a European Borderland: Occupations and Occupation Plans in Galicia and Ukraine, 1914-1918. U of Washington P, 2007. Donald W. Treadgold Studies on Russia, East Europe, and Central Asia. 